\title{
Integration of the primary health care approach into a community nursing science curriculum
}

\author{
SS Vilakazi, M. Cur. RAU \\ MM Chabeli, M.Cur, Department of Nursing Science, RAU \\ SD Roos, D.Cur, Department of Nursing Science, RAU
}

\section{Abstract}

The purpose of this article is to explore and describe guidelines for integration of the primary health care approach into a Community Nursing Science Curriculum in a Nursing College in Gauteng. A qualitative, exploratory, descriptive and contextual research design was utilized. The focus group interviews were conducted with community nurses and nurse educators as respondents. Data were analysed by a qualitative descriptive method of analysis as described in Creswell (1994:155). Respondents in both groups held similar perceptions regarding integration of primary health care approach into a Community Nursing Science Curriculum. Five categories, which are in line with the curriculum cycle, were identified as follows: situation analysis, selection and organisation of objectives/ goals, content, teaching methods and evaluation. Guidelines and recommendations for the integration of the primary health care approach into a Community Nursing Science Curriculum were described.

\section{Uittreksel}

Die doel van hierdie artikel is om riglyne te bepaal en te beskryf vir integrasie van die primêre gesondheidsorgbenadering in ' $n$ Gemeenskapsverpleegkundekurrikulum in ' $n$ Verplegingskollege in Gauteng. ' $n$ Kwalitatiewe, verkennende, beskrywende en kontekstuele navorsingsontwerp is gebruik. Die fokusgroeponderhoude is met gemeenskapsverpleegkundiges en dosente in verpleegkunde as respondente gevoer. Data is ontleed deur middel van ' $\mathrm{k}$ kwalitatiewe, beskrywende metode soos beskryf deur Creswell (1994:155). Respondente in beide groepe het soortgelyke persepsies betreffende integrasie van die primêre gesondheidsorgbenadering in ' $n$ Gemeenskapsverpleegkunde-kurrikulum. Vyf kategorieë, in ooreen-stemming met die kurrikulumsiklus, is as volg geïdentifiseer: situasie-analise, keuse en organisering van objektiewe/doelwitte, inhoud, onderrigmetodes en evaluering. Riglyne en aanbevelings vir die integrasie van die primêre gesondheidsorgbenadering in ' $n$ Gemeenskapsverpleegkunde-kurrikulum is beskryf.

\section{Introduction}

According to the South African Government and community health requirements, a nurse on training must be comprehensively prepared to function independently in the primary health care setting (White Paper, 1997:60-63). The existing nurse training for a comprehensive basic diploma, is based on curative services rather than on the community. This creates a gap in that the primary health care approach is not adequately integrated into a Community Nursing Science Curriculum.

From the observations made by the researcher, the existing nurses' training in a Nursing College in Gauteng, does not prepare the nurses to be functional in the primary health care setting. According to the ANC's National Health Plan (1994:79) the training of the health workers has been inappropriate with regard to health needs. As a result of this inappropriateness, the need exists for change in the basic training and development of new categories of health personnel. The health care system demands more relevant and competent nurses to implement the primary health care approach.

In view of the above concerns and facts, it is necessary to describe guidelines for the integration of the primary health care approach into a Community Nursing Science Curriculum in a Nursing College in Gauteng. This raises the question: How can the primary health care approach be integrated into a Community Nursing Science Curriculum? Hence the purpose of the study was to explore and describe guidelines for the integration of the primary health care approach into a community nursing science curriculum. This purpose is realised by the following objectives:

- To explore and describe the perceptions of community nurses regarding the integration of the primary health care approach into a Community Nursing Science Curriculum in a Nursing College in Gauteng.

- To explore and describe the perceptions of nurse educators regarding the integration of the primary health care approach into a Community Nursing Science Curriculum in a Nursing College in Gauteng.

- To describe guidelines for the integration of primary health care approach into a Community Nursing Science Curriculum in a Nursing College in Gauteng. 


\section{Terminology}

\section{Integration}

In this article, integration means organisation of the community nursing science content into a close relationship with the primary health care approach concepts, skills and values to constitute an integrated curriculum.

\section{Curriculum}

In the context of this article, curriculum means a Community Nursing Science Educational Programme developed to integrate primary health care in the education and training of the student nurse.

\section{Student nurse}

The student nurse is an adult learner who has been selected for a four year basic diploma course leading to registration as a nurse (General, Psychiatric, Community) and Midwife at a Nursing College.

\section{Community nurse}

A community nurse is a professional nurse who is registered with the South African Nursing Council to render health care services in the community/primary health care setting.

\section{Nurse educator}

A nurse educator is a professional nurse who is registered with the South African Nursing Council. He/she is prepared to educate, train and guide student nurses to become independent practitioners.

\section{Community Nursing Science}

Community Nursing Science is a speciality field in nursing practice which synthesizes knowledge and skills from nursing and community health and applies them toward the promotion of optimal health.

\section{Primary Health Care}

Primary Health Care "is essential care based on practical, scientifically sound, acceptable methods and technology made universally accessible to individuals and families in the community through their full participation and at the cost that the community and the country can afford to maintain at every stage of their development in the spirit of self-reliance and self-determination. It forms an integral part of both the country's health systems, of which it is the central function and main focus, and of the overall social and economic development of the community" (WHO, 1975:16).

\section{Research design and method}

A qualitative, exploratory, descriptive and contextual research design was utilized (Mouton, 1996:107; Woods \& Catanzaro, 1998:150). The research method was divided into three phases. The focus group interviews were used to collect data from community nurses (Group A) and nurse educators (Group B). In phase 1, ten community nurses participating in training of four year basic diploma student nurses, in the primary health care setting for a minimum of three years were purposively selected from the District Health Authority in
Western Vaal Metropolitan Substructure. In phase 2, ten nurse educators having community nursing science qualification, teaching four year basic diploma student nurses in a West Rand Region Nursing College in Gauteng Province for a minimum of three years were purposively selected. In phase 3, the guidelines based on the conclusions deduced from the results of phase 1, phase 2 and literature control were described. Conclusions and recommendations were also made. The interviews were conducted following explanation of the purpose and process of the study. Respondents in both groups were asked the same two questions: (I) What are your perceptions regarding integration of the primary health care approach into a Community Nursing Science Curriculum for student nurses following a four year basic comprehensive diploma course? (ii) How can the primary health care approach be integrated into a Community Nursing Science Curriculum? To explore the perceptions following two questions, subsequent questions were dependent on responses of both group A and group B respondents. A tape recorder was used with the permission of both groups of respondents while the researcher took field notes to validate data collected.

A suitable, unused, noise free room was used to facilitate privacy, confidentiality and protection from discomfort and harm. Consent to participate in the research was obtained from participants. Follow-up interviews were conducted with three respondents from each group to validate some aspects of the data that was collected.

Data collected were analysed using Tech's methods (in Creswell, 1994:155). The eight steps of this method were followed. A qualified data analysis specialist and an independent coder was employed. Consensus on categories was reached between the independent coder and researcher regarding the categories to ensure trustworthiness of data analysis and the coding of data collected. Comparison of the analysis was done and consensus was reached about the categories of units of analysis. The themes were then based on the similar ideas as perceived by respondents in phase 1 and phase 2 of the study.

The model of Guba (in Lincoln and Guba, 1985:289-300) was used throughout the study to ensure trustworthiness. The four strategies for trustworthiness namely transferability for applicability, credibility for truth value, dependability for consistency and confirmability for ensuring neutrality were applied. The researcher accomplished the transferability of this study by means of purposive sampling of both community nurses and nurse educators. The dense description of data provides the basic information to other researchers if needed to prove transferability. Credibility was achieved by prolonged engagement, triangulation, member checking, peer examination and authority of the researcher. Prolonged engagement was ensured by spending one hour per focus group interview. The respondents were given all necessary information related to the study. Triangulation of data collection and data control was executed. An independent coder was used to analyse data and to validate data gathered in this study. Experts in qualitative research were also used in discussing the process and results of the study. Member checking occurred by conducting follow-up interviews with a view to verify data interpretation. To ensure dependability a complete description of methodology, including verbatim transcription of data was also given. The audit trial technique was used to 
establish confirmability through an inquiry audit, to ensure truth and accuracy of the study.

\section{Findings}

The findings were deduced from the response made by both community nurses and nurse educators during the focus group interviews. Both respondents held similar perceptions with regard to integration of the primary health care approach into a Community Nursing Science Curriculum. Five categories which are in line with curriculum cycle (Nicholls and Nicholls, 1972:21) were identified as follows:

Situation analysis, selection and organisation of the objectives/goals, selection and organisation of content, selection and organisation of methods and evaluation (see Table 1). a Community Nursing Science Curriculum because it is an essential service that must be made equitable, accessible, acceptable and affordable to the communities throughout the country.

- A paradigm shift in nursing education from curative care towards promotive health is necessary. This means a shift towards comprehensive health care approach. The implication of this paradigm shift from institutionalised care to a community based care, means that the education and training of student nurses in Community Nursing Science need to move from the curative situation to a situation where more emphasis is placed on community based education. The perceptions of the respondents in this regard is evidenced by the following quotations:

\section{TABLE 1: Categories}

\section{CATEGORIES PHASE 1 AND PHASE 2}

1. Situation analysis as the first step in integration of the primary health care approach into a Community Nursing Science Curriculum.

- Philosophy of an integrated Community Nursing Science Curriculum.

- Students as the recipients of an integrated Community Nursing Science Curriculum.

- Nurse educators/community nurses as learning facilitators of the student nurses in an integrated Community Nursing Science Curriculum.

- Community involvement in an integrated Community Nursing Science Curriculum.

2. Selection and organisation of objectives/goals of an integrated Community Nursing Science Curriculum.

3. Selection and organisation of content of an integrated Community Nursing Science Curriculum.

4. Selection and organisation of methods in an integrated Community Nursing Science Curriculum.

5. Evaluation in an integrated Community Nursing Science Curriculum.

\begin{abstract}
- Situation analysis as the first step in the integration of the primary health care approach into a Community Nursing Science Curriculum

Information which will contribute towards development and implementation of an integrated curriculum gathered from both respondents included: philosophy, students, nurse educators/ community nurses and community involvement.
\end{abstract}

* Philosophy of the integration of the primary health care approach into a Community Nursing Science Curriculum

The respondents indicated that the philosophy of an integrated Community Nursing Science Curriculum should be based on the following beliefs:

- Health is a basic human right. Each individual has to take responsibility for his or her own health though vulnerable groups in the community should be taken care of by community nurses with maximum community involvement. It is necessary to integrate the primary health care approach into
"Integrating primary health care approach into a Community Nursing Science Curriculum is acceptable. This means moving away from the curative services approach towards a promotive health."

"The integrated Community Nursing Science Curriculum must make provision for services that are equitable, affordable, acceptable and available to all members."

"Primary health care approach must be integrated into community nursing science because it is a basic human right, each individual must take responsibility to look after his own health in totality, but on the other hand vulnerable groups in the community should be taken care of by the community nurses and trained health care workers.

Hills and Lindsey (1994:222) states that there is a need to shift from the medical paradigm to the primary health care approach in order to train and educate students for primary health care practice. On the other hand the National Health Plan for South Africa (ANC, 1994:2) states that primary health care is an essential service that must be made accessible, ac- 
ceptable, available and affordable to the community throughout the country.

It is concluded that the philosophy of the integrated Community Nursing Science Curriculum has to be based on the belief that health is a basic human right. Health has to be equitable, available and affordable to communities throughout the country. Each individual needs to take responsibility for his or her own health although vulnerable groups in the community should be taken care of by the community nurses with maximum involvement.

* Student nurses as recipients of an integrated Community Nursing Science Curriculum

The respondents indicated that student nurses need to be prepared holistically in order to function independently in the primary health care setting and must have the ability to communicate effectively with families. The respondents are quoted as saying: "The integration of the primary health care approach in a comprehensive course will equip students holistically. They will be able to nurse patients in totality, taking into consideration the culture values and norms of the community."

Spradley $(1990: 192)$ indicates that clinical nursing is holistic in nature but in reality patients are viewed as a larger system in terms of a family or group, therefore they must be cared for in totality by comprehensively trained nurses.

Knowles (1980:43) perceives student nurses as adult learners who have qualities of positive self-concept, experience, learning readiness and positive orientation to learning. Long (1993:240) and Reed Procter (1993:31) also reiterate the abovementioned perception.

It is therefore necessary that student nurses as recipients of an integrated Community Nursing Science Curriculum possess a positive self-concept in order to be self directed, self controlled, responsible and to determine own learning needs.

* Nurse educators/community nurses as learning facilitators of student nurses in an integrated Community Nursing Science Curriculum

The respondents indicated that the community nurses/nurse educators need to be knowledgeable and clinically skilful. This means that community nurses/nurse educators must be experts in an integrated Community Nursing Science Curriculum, both theoretically and practically. As learning facilitators, expertise in health promotion, health assessment, treatment and care, and community-based education is essential in order to guide the student nurses to become independent practitioners in the primary health care setting. This is evidenced by the quotations: "All community nurses should be knowledgeable and clinically competent of what the student should be equipped with when they complete the course." "College tutors and community nurses should have a way of communicating, discuss what is to be done for the students." "As a facilitator in the integration of the primary health care approach into a Community Nursing Science Curriculum, the nurse educator should provide some opportunities for the student to think critically."

Mellish and Brink (1998:7) mention that to be an effective teacher, one needs to be a subject expert and have teaching skills as well as good relations with students.

It is important that the learning facilitators of student nurses need to be Community Nursing science experts both theoretically and clinically. Learning facilitators need expert skills in health promotion, health assessment, treatment and care, effective communication and collaboration with the multidisciplinary health team in order to develop the capacity of student nurses to become independent practitioners.

* Community involvement in an integrated Community Nursing Science Curriculum

The respondents maintain that community involvement in an integrated Community Nursing Science Curriculum is necessary since the members of the community are consumers of the primary health care services and can realise their health care needs. In reality members of the community need to participate in the curriculum development committee responsible for developing the integrated curriculum. This includes the involvement of traditional healers, complementary healers and all other stakeholders in the implementation of the integrated curriculum. The respondents were quoted as saying: "Community nurses must involve the community in finding ways of meeting their needs. This approach will make community to own the clinic and look after it." "Traditional healers and spiritual healers are to be included in the syllabus as many patients still prefer their support in illness." "The Government also approves the contributions they make in health promotion."

The respondents further indicated that the community involvement will facilitate mobilisation and availability of community resources that are needed in the primary health care setting to meet the students learning needs. Respondents were quoted as saying: "Because whatever we prescribe in the curriculum, must go hand in hand with the resources. There is no point in telling the students to do this, and when they go to the actual situation you'll find that the resources are not shaping with the students needs."

"If primary health care is integrated into a community nursing science you are looking at expanding the resources that are available so that the resources can be accessible and feasible to everybody."

The National Health Plan (ANC, 1994:21) emphasizes accountability and community participation as an important principle in primary health care approach. Fairley (1993:224) reiterates this idea. Troskie (1997:24) indicates that traditional healers have been a central component of African medicine. Edelstein and Sanders (1998:21) found that more specific issues relevant to community partnership, such as relationships with traditional healers, should be included in the curricula.

The researcher perceives that it is necessary to involve the community in the development and implementation of an integrated curriculum. Since it is a process of consultation and collaboration. The members of the community need to participate in the integrated curriculum development committee to ensure community and practice driven curricula 
- $\quad$ Selection and organisation of goals/objectives of an integrated Community Nursing Science Curriculum

The respondents indicated that the goals of an integrated Community Nursing Science Curriculum need to aim at preparation of student nurses to become independent practitioners in promotive and preventive health care services, to move away from curative to promotive health care, to develop lifelong learners, who are self-directed, reflective and critical thinkers.

This was evidenced by the following quotations: "Student nurses should know from the beginning that they are going to be independent practitioners. Students must know how to assess, diagnose and treat patients on their own." "Integrating primary health care approach into a Community Nursing Science Curriculum, means moving away from curative services to preventive and promotive health care. We are moving towards providing comprehensive health service ...... is nationally acceptable according to the National Health Policy."

Beddone and Budgen (1995:14) recommend that the graduates of the curriculum are to be independent, self-directed, self-motivated and must have the ability to make clinical judgements based on reflective thinking.

It is deduced from the discussion and philosophy that the goals of an integrated Community Nursing Science Curriculum are to enable students to become independent practitioners who are self-directed and self-motivated. Therefore, there is need to move from curative to promotive health.

\section{- Selection and organisation of content of an inte- grated Community Nursing Science Curriculum}

The respondents revealed similarities in the perceived content of the integrated Community Nursing Science Curriculum as follows:

\section{* Health promotion}

The respondents indicated that students should be equipped with health promotion skills in order to promote health in the community. They further mentioned that students should come in contact with a healthy person before coming in contact with a person who has health problems. Respondents were quoted as saying: "The students should be equipped with health promotion skills. They must exactly know what to do, in order to provide health care in the community. They must be taught how to identify problems in the community .... so that throughout their training career, they must..... apply these skills."

"The other thing should be ..... to put students in families .... so that they will learn normal family life before you bring them in contact with the ill person."

Bestard and Courtenay (1990:24-25) suggest that, during the first year of training, student nurses should be placed in the clinical area where the nursing focus will be on the promotion of health and development. Thus student nurses need to be equipped with health promotion skills such as health assessment skills, communication skills, interactive skills, health education skills and problem-solving skills.

* Health assessment, treatment and care

Respondents pointed out that student nurses should be trained in health assessment, treatment and care to enable them to perform family health assessment, and to provide treatment and care. Respondents were quoted as saying: "Students should be educated on health assessment and identification of common diseases in the community and they should do related practica." "Students must know how to diagnose prevalent diseases in the community, including minor ailments, health hazards and problems as well as the needs of young people."

The American Association of College of Nursing (AACN, 1993 in Oermann, 1994:219) recommended that student nurses should be empowered with health assessment skills, treatment skills, health care and education skills, to prepare them for their role as independent practitioners. It is then necessary to teach student nurses health assessment, treatment and care of common health problems prevalent in the community.

\section{* Epidemiology}

Education and training of student nurses to acquire epidemiological skills, amongst others to be able to gather statistics on health needs/problems and factors influencing health patterns and practices in the primary health care setting was perceived essential by the respondents.

The respondents indicated the following: "Epidemiology need to be integrated in the curriculum as it helps to assess, diag. nose, plan and evaluate interventions in the community." Respondents further mentioned that: "Keeping health information plays an important role in the delivery of primary health care, statistics on mortality, morbidity, births and death rates; information on violence, road accidents, environmental hazards, good nutrition, prevention of communicable diseases, especially endemic diseases including sexually transmitted diseases, AIDS and HIV infections. Immunization of children, treatment of minor ailments, health education and communication skills and insect control should be part of the integrated curriculum."

Clark (1996:99) and Dryer et. al (1993:63) indicate the importance of epidemiology at all levels of primary health care Community nurses use epidemiology principles to assess, plan, evaluate interventions and to promote health. The epidemiological skills, especially statistics on health profiles, patterns and practices are a problem in South Africa (White Paper, 1997:78). This epidemiological skills such as the gathering of statistics, health practices/patterns and health problem profiles are necessary.

\section{* Transcultural health issues}

Respondents indicated the importance of preparing student nurses in respect of transcultural health issues in order to equip them with skills to deal with multicultural health problems in the varied primary health care setting. Respondents were quoted as saying: "Student nurses on training must be educated to be sensitive towards the norms, values, customs, beliefs and practices of patients and people they are working with." "The transcultural issues that exist in the community play an important role in caring of patients, thus students must be taught how to deal with multicultural problems and needs of the patients." 
Andrews (1995:4) maintains that the transcultural nursing is an influential force in transforming contemporary nursing education as students learn to function in a multicultural world in which people expect their cultural values and life styles to be respected and understood. Student nurses need to be prepared to respect the transcultural health issues. They need to be equipped with skills to assess multicultural health problems and how these problems are resolved.

\section{* Health related legislation}

The respondents mentioned that student nurses need to be educated and trained about the laws, regulations and health related legislation which provide a legal framework for practising independently as community nurses in the primary health care setting. This is evidenced by the following quotations: "In the primary health care delivery system, students are to be educated about the laws and regulations which control the scope of their practice, health legislation and health related laws in the country." "The related legislation should include, the Nursing Amendment Act 5 of 1995, Regulation for the Scope of Practice R2676 of 1990, the Termination of Pregnancy Act, Regulations for Registration as a Community Nurse, the Medicine and related Substance Control Amendment Act 90 of 1997, which allows nurses to prescribe medicine, the National Health Policy and Labour Relations Amendment Act 42 of 1996, which improves the industrial relationships."

Berman and Muller (1994:32) recommend that the principles of reading and interpreting health care legislation should be included in all health care professional education programmes. Edelstein and Sanders (1998:15) reiterate this idea. In view of the above discussion, the legal framework for community nurses practising primary health care appeared inadequately covered in the education and training of student nurses. It is necessary to include health related legislation such as the Termination of Pregnancy Act (Act 92 of 1996), the SA Constitution (Act 108 of 1996), the National Health Policy, the Nursing Amendment Act (Act 5 of 1995), the Medicine and Related Substance Control Amendment Act (Act 90 of 1997) and the Labour Relations Amendment Act (Act 42 of 1996) in the education and training programme of student nurses.

\section{* Intersectoral and interdisciplinary collaboration}

The respondents indicated that student nurses need to be prepared to acquire skills in intersectoral collaboration to enable them to form a network with health related sectors with a view to consultation and referral in the provision of primary health care in the community. Respondents were quoted as saying: "Syllabus should integrate all those health related services and community organisations that played a role in the provision of primary health care services, for example: water supply, basic sanitation, electrification, housing, nutrition, generation of employment small business development, transport and education because if a patient is having a problem with one or more of the above-mentioned services, he may present with a constant health problem thus he will need appropriate referral." "Students must receive adequate knowledge on the referral system, for example social workers, physiotherapist and other organisations that are health related."
The National Health Plan (ANC, 1994:21) emphasizes intersectoral collaboration with the sectors that have a bearing on the integration of the primary health care approach into a Community Nursing Science Curriculum. It is deduced that the Community Nursing Science Curriculum for education and training of student nurses does not adequately integrate the services of other health related sectors. It is therefore necessary that the intersectoral collaboration be included in the core content of an integrated Community Nursing Science Curriculum in order to prepare student nurses to acquire skills in intersectoral collaboration.

- Selection and organisation of methods to be followed in an integrated Community Nursing Science Curriculum Respondents indicated the learning opportunities/methods that need to be utilized in the implementation of the integrated curriculum as follows:

\section{* Interactive learning opportunities/methods}

Respondents indicated a need for placement of the student nurse in the primary health care setting, with some guidelines to direct her/him. This will enable the student nurse to interact with healthy persons while doing family studies before placement in a curative health care situation. The placement of the student in the primary health care setting at this level of training prepares the student to acquire skills in health assessment and family involvement which are necessary for health promotion. Respondents were quoted as saying: "Students should be placed in the community first, before they can be allocated in the hospital situation. Each student should be placed in a family with some guidelines on what to look for ..... a sort of a workbook."

Respondents further emphasized the use of fewer lectures in the implementation of an integrated Community Nursing Science Curriculum emphasis must be on the utilization of reflective teaching, learning methods, such as fieldwork, seminars and interactive group discussions. Respondents were quoted as saying: "It is essential that less lectures should be given and experiential and reflective teaching methods should be used such as fieldwork, group discussions, brainstorming and seminars. These methods provide opportunities for newlylearned skills and thus promote reflective learning and reflective thinking."

Fuszard (1995:81) mentions that family studies as a method of teaching and learning facilitate the application of theory to real-life situations. Eshleman and Davidhizar (1997:27) indicate that the implementation of the curriculum involves actual community experiences for the students. It is concluded that student nurses as adult learners with adult characteristics need to be placed in the community first, prior to exposure in the curative health care situation.

* Extensive integrated community clinical experiences Respondents mentioned that students should do more practical work in the primary health care setting. Primary health care experiences should be integrated throughout community nursing science practicals. Clinical experiences should provide learning opportunities for development of skills in health promotion in various settings. Extensive community practice helps the students to develop knowledge and skills in providing care to patients in the community and in the man- 
agement of acute and chronic health problems. Respondents were quoted as saying: "Students have to do more practica at the primary health care setting, if we want to come out with nurses who are good in practica."

"Primary health care experiences should be integrated throughout their practice and should provide learning opportunities for development of skills in health promotion, prevention of illness and management of both acute and chronic illnesses, as well as minor ailments. " "Out of the total number of hours that are allocated for their practice .... they should be given something like $60 \%$ to spend in the community and $25 \%$ at the clinic from the first year until the last year of their training." "If possible it would be advisable that students should be accompanied ... so that if theory is needed, the tutors are there to facilitate with their knowledge, if possible, especially on the first day, they should be accompanied by a tutor."

Oermann (1994:216) maintains that clinical learning experiences in the community provide an opportunity for students to participate in health promotion in various settings. De Tornyay (1993:302 - 306) states that students need to be accompanied in the community clinical situation.

It is necessary that the placement of student nurses in the primary health care setting should be increased from the first year to the last year of their training. Student nurses need to be accompanied by learning facilitators in the primary health care setting. Student nurses will benefit more because the learning facilitators will be able to orientate them to provide the necessary guidance on how to acquire meaningful integrated learning experiences in health promotion.

\section{- Evaluation in an integrated Community Nursing Science Curriculum}

The perceptions of the respondents regarding evaluation in an integrated Community Nursing Science Curriculum are based on student-orientated and curriculum-orientated evaluation.

\section{* Student-orientated evaluation}

The respondents indicated that: Students should be given a chance to evaluate themselves and formative and summative evaluation should be done because both methods assist in determining students progress. They further pointed out that both tutors and community nurses who participated in the training and education of student nurses should participate in the evaluation of the practical component of an integrated Community Nursing Science Curriculum. They also indicated that it would be ideal if continuous clinical evaluation and clinical examination took place in the actual community clinical situation, that is at the clinics where the students have clinical learning experiences. Evaluation should take place immediately following clinical exposure to establish student competence. This is evidence by the following quotations:

"Students should be given a chance to evaluate..... themselves." "Both tutors and community nurses who participated in the training and education of students should participate in the evaluation of the practical component of the integrated curriculum to determine the skills acquired in respect of each level of training." "It will be ideal if the clinical examina- tion and continuous evaluation should take place in the actual community clinical situation, that is the clinics where students receive clinical experiences. The evaluation should take place immediately following clinical exposure to establish student competence." "Formative and summative evaluation should be done because both evaluations assist to determine whether the students are ready to progress to the next level or course of training and education. Summative evaluation should be in a form of a project."

Fuszard (1995:7) states that an educator must provide guidance on self-evaluation regardless of the learning skills required. Van der Horst and McDonald (1997:194) mentioned that there is a need for a record in which some detail about what learners have accomplished as a result of their experiences in the learning situation can be documented. Such records are portfolios which provide evidence of learners knowledge, skills, attitudes and academic development. It is important that student nurses need to be given an opportunity to perform self-evaluation against a given criteria. There is also a need for portfolios as they involve both the learning facilitators and student nurses in the primary health care setting in an integrated Community Nursing Science Curriculum. It is important that both nurse educators and community nurses who participate in the education and training of student nurses, take part in the clinical evaluation of an integrated Community Nursing Science Curriculum.

\section{* $\quad$ Curriculum-orientated evaluation}

Respondents mentioned that research needs to be done after four years following implementation of the integrated curriculum, in order to evaluate the entire integration process of the curriculum. They further indicated that the community as the recipient of primary health care services needs to be involved in the evaluation of an integrated Community Nursing Science Curriculum. The respondents were quoted as saying: "We can do research after four years to evaluate the whole integration process." "Consider also checking with the very recipient of the service ..... the community."

Carl (1995: 1 19) emphasizes curriculum orientated evaluation as it seeks to determine the extent to which the objectives of the curriculum have been achieved. It is therefore essential to do continuous evaluation of the integrated curriculum, based on the objectives, so as to evaluate whether the integration of the primary health care approach into a Community Nursing Science Curriculum has really materialized.

\section{Guidelines}

The guidelines are described for nurse educators and community nurses on integration of the primary health care approach into a Community Nursing Science Curriculum for a four year comprehensive basic diploma course (General, Psychiatric, Community) and Midwife based on the following categories: situation analysis, goals/objectives, content, methods/learning opportunities and evaluation (see Table 2).

\section{Conclusion and recommendations}

The purpose of this article was to describe guidelines for the integration of the primary health care approach into a Com- 
munity Nursing Science Curriculum in a Nursing College in Gauteng Province. The recommendations made are based on the results of this study and the application thereof in nursing education, nursing practice and nursing research.

The recommendation are that:

- The guidelines described in this study could be used to implement an integrated Community Nursing Science Curriculum in the primary health care setting.

- The nurse educators/community nurses could use the guidelines described in this study to improve the practice in primary health care setting.

- The guidelines describe for integration of the primary health care approach into a Community Nursing Science Curriculum could be used to generate hypotheses to be tested in the future with a view to improve health care practice.

- A model to enhance integration of primary health care approach into a Community Nursing Science Curriculum, be developed using the described concepts for deriving the conceptual framework in Nursing Education in South Africa.

\section{Conclusion}

Based on the above discussions, it is recommended that the described recommendations and guidelines be applied in Nursing Education to improve primary health care. 


\section{TABLE 2: Guidelines for integration of the primary health care approach into a community nursing science curriculum}

\begin{tabular}{|l|l|}
\hline CATEGORIES & GUIDELINES \\
\hline $\begin{array}{l}\text { 1. Situation analysis as the first } \\
\text { step in integration of the primary } \\
\text { health care approach into a Com- } \\
\text { munity Nursing Science Curricu- } \\
\text { lum. }\end{array}$ & $\begin{array}{l}\text { Philosophy of the integrated curriculum. } \\
\text { ing science educators should ensure that: }\end{array}$ \\
$\begin{array}{ll}\text { must be equitable, affordable, accountable and available to all members of the commu- } \\
\text { nity. }\end{array}$ \\
$\begin{array}{l}\text { Individuals are expected to take responsibility for their own health and that } \\
\text { priority should be given by community nurses to vulnerable groups, such as the } \\
\text { aged, the poor, the under served, women and children. }\end{array}$
\end{tabular}

\subsection{Student nurses' characteristics desirable for the integrated curriculum}

Nurse educators should ensure that prospective student nurses who enter an integrated Community Nursing Science Curriculum possess the essential characteristics of an adult learner which should enable nurses to function holistically and independently in the primary health care setting. These characteristics are:

- $\quad$ Self-concept

Since student nurses are expected to function independently in the primary health care setting a positive self-concept should enable them to be self-directed, self-regulated and responsible for their own learning. Student nurses should demonstrate willingness and receptiveness to acquire new learning experiences in the primary health care setting.

- Experience

As an adult learner, student nurses should bring to the primary health care situation a wide and diverse source of experience. They should link experiences to knew knowledge in the primary health care setting.

- $\quad$ Learner readiness

Student nurses' readiness to learn relates to their real-life concerns in terms of knowledge, skills, attitudes and values which an adult learner should possess and apply in the primary health care setting. Student nurses should participate actively in their own learning. They should appreciate the learning experiences in the primary health care setting.

- $\quad$ Learner orientation

As adult learners, student nurses are expected to have a problem-solving and task orientated approach to learning, they need to apply the knowledge acquired in the learning situation immediately.

\subsection{Nurse educators/community nurses as learning facilitators}

- Nurse managers in community nursing Science education should ensure that nurse educators/community nurses responsible for education and training of student nurses possess the following characteristics:

Skills in health promotion, health assessment, treatment and care and community based education, in order to guide student nurses to become independent practitioners in primary health care setting.

Effective communication with student nurses is essential to facilitate student centred learning.

- They must collaborate with intersectoral/multi-disciplinary health teams to develop the capacity of students to become independent practitioners in the primary health care setting.

- Nurse educators/community nurses should possess reflective thinking skills to guide student nurses in their clinical practice, and be self-confident, flexible, openminded and non-judgmental in facilitating learning in primary health care setting.

\subsection{Community involvement}

- All stake holders involved in the development of an integrated Community 


\begin{tabular}{|l|}
\hline CATEGORIES \\
\hline $1 . \quad$ Situation analysis as the first \\
step in integration of the primary \\
health care approach into a Com- \\
munity Nursing Science Curricu- \\
lum.
\end{tabular}

\section{GUIDELINES}

1.1 Philosophy of the integrated curriculum.

When the philosophy about the integrated curriculum is developed, community nursing science educators should ensure that:

- Emphasis is placed in the philosophy that health is a basic human right that must be equitable, affordable, accountable and available to all members of the community.

- Individuals are expected to take responsibility for their own health and that

- $\quad$ priority should be given by community nurses to vulnerable groups, such as the aged, the poor, the under served, women and children.

\subsection{Student nurses' characteristics desirable for the integrated curriculum}

Nurse educators should ensure that prospective student nurses who enter an integrated Community Nursing Science Curriculum possess the essential characteristics of an adult learner which should enable nurses to function holistically and independently in the primary health care setting. These characteristics are:

\section{- $\quad$ Self-concept}

Since student nurses are expected to function independently in the primary health care setting a positive self-concept should enable them to be self-directed, self-regulated and responsible for their own learning. Student nurses should demonstrate willingness and receptiveness to acquire new learning experiences in the primary health care setting.

- $\quad$ Experience

As an adult learner, student nurses should bring to the primary health care situation a wide and diverse source of experience. They should link experiences to knew knowledge in the primary health care setting.

- Learner readiness

Student nurses' readiness to learn relates to their real-life concerns in terms of knowledge, skills, attitudes and values which an adult learner should possess and apply in the primary health care setting. Student nurses should participate actively in their own learning. They should appreciate the learning experiences in the primary health care setting.

- Learner orientation

As adult learners, student nurses are expected to have a problem-solving and task orientated approach to learning, they need to apply the knowledge acquired in the learning situation immediately.

\subsection{Nurse educators/community nurses as learning facilitators}

- Nurse managers in community nursing Science education should ensure that nurse educators/community nurses responsible for education and training of student nurses possess the following characteristics:

- $\quad$ Skills in health promotion, health assessment, treatment and care and community based education, in order to guide student nurses to become independent practitioners in primary health care setting.

Effective communication with student nurses is essential to facilitate student centred learning.

They must collaborate with intersectoral/multi-disciplinary health teams to develop the capacity of students to become independent practitioners in the primary health care setting.

- $\quad$ Nurse educators/community nurses should possess reflective thinking skills to guide student nurses in their clinical practice, and be self-confident, flexible, openminded and non-judgmental in facilitating learning in primary health care setting.

\subsection{Community involvement}

- All stake holders involved in the development of an integrated Community 


\begin{tabular}{|c|c|}
\hline CATEGORIES & GUIDELINES \\
\hline & $\begin{array}{l}\text { Nursing Science Curriculum should form part of the curriculum committee, that is } \\
\text { community representatives, and alternative traditional healers. } \\
\text { - All those involved in the development of the integrated curriculum should iden- } \\
\text { tify community health needs problems and assist in the planning of student nurses' } \\
\text { educational programmes. } \\
\text { - They should identify community resources for student placement in the clinical } \\
\text { area, for example voluntary organisations, facilities for the aged and people with health } \\
\text { problems. } \\
\text { - They must also point out the existence of transcultural health practices and ex- } \\
\text { pectations that should be integrated in the curriculum and create self-reliance and mo- } \\
\text { tivation in the community to participate in responsible and accountable decision-mak- } \\
\text { ing and in the provision of primary health care services. } \\
\text { - A true partnership must be established between community nurses and commu- } \\
\text { nity members in order to create a common ground to discuss different points of view in } \\
\text { health practices and cultural health patterns in the community. } \\
\text { - Community resources must be mobilised and made available, accessible and } \\
\text { feasible to those involved in developing the integrated curriculum within the primary } \\
\text { health care setting. }\end{array}$ \\
\hline $\begin{array}{l}\text { 2. Selection and organisation } \\
\text { of goals/objectives of an inte- } \\
\text { grated Community Nursing Sci- } \\
\text { ence Curriculum }\end{array}$ & $\begin{array}{l}\text { The goals of an integrated curriculum should be: } \\
\text { to prepare student nurses to become independent practitioners who are self- } \\
\text { directed and self-motivated. } \\
\text { - to move from curative to promotive health. In order to achieve these goals, } \\
\text { nurse educators/community nurses should set appropriate objectives regarding the fol- } \\
\text { lowing: Health promotion, health assessment, treatment and care, epidemiology, } \\
\text { transcultural health issues, health related legislation, interdisciplinary and intersectoral } \\
\text { collaboration, communication and health supportive skills. }\end{array}$ \\
\hline $\begin{array}{l}\text { 3. Selection and organisation } \\
\text { of content of an integrated Com- } \\
\text { munity Nursing Science Curricu- } \\
\text { lum }\end{array}$ & $\begin{array}{l}\text { The content related to the primary health care approach should include the following: } \\
\text { 3.1 Health promotion } \\
\text { health promotion. Health promotion education should include knowledge and skills in } \\
\text { health assessment, communication, interaction, health education, problem-solving, the } \\
\text { study of healthy person and identification of common health problems in the primary } \\
\text { health care setting. } \\
\text { - Health education should be provided on common health problems and treatment } \\
\text { of minor injuries at clinics, schools, work places and family environment. } \\
\text { 3.2 Health assessment, treatment and care } \\
\text { Education and training of student nurses by nurse educators/community nurses should } \\
\text { include: } \\
\text { - Assessment of individuals with common health problems and provision of treat- } \\
\text { ment and care, for example in the case of headache, stomachache, diarrhoea and vom- } \\
\text { iting. } \\
\text { - Identification of traditional health patterns and practices and including them in } \\
\text { health care plans, for example acupuncture, enemas, herbal treatment, herbal tea. } \\
\text { - Involvement of members of the community to develop the capacity to assess } \\
\text { their own health needs, problems and to identify appropriate intervention actions. } \\
\text { - Encouragement of individuals to carry out self-care and treatment, for example } \\
\text { administration of medication, dressing of minor wounds, urine testing and administra- } \\
\text { tion of insulin. } \\
\text { 3.3 Epidemiology } \\
\text { Nurse educators/community nurses should educate and train student nurses to acquire } \\
\text { skills in epidemiology in order to: } \\
\text { - Gather common health problem profiles by keeping records of people who visit }\end{array}$ \\
\hline
\end{tabular}


the clinic with common health problems in terms of frequency, age group, geographical area, cultural groups, gender, social class, occupation.

- Compile proper and adequate health statistics on mortality, morbidity of all age groups, births, deaths, injuries, disability, violence accidents.

- Conduct community health surveillance with maximum active community involvement

- $\quad$ Keep and make available accurate information for primary health care plans and interventions, for example health indicators such as mortality rates, birth rates, breast-feeding rates, age-specific substance abuse such as tobacco, drugs, alcohol, HIV incidence rates and clinic attendance rates.

- Gather information on the use of traditional treatment for its applicability and contribution in promotive health. Traditional healers should be involved in mini surveys on common health problems in the community.

- Student nurses should be trained in the analysis and use of data related to common health needs/problems.

\subsection{Transcultural health issues}

Community nurses/nurse educators should educate student nurses in respect of transcultural issues in order to:

- Understand traditional health values, beliefs and customary patterns and practices in dealing with health problems.

- $\quad$ Enable student nurses to interact with different cultural groups.

- $\quad$ Provide for common multi-cultural health needs/problems and to acquire knowledge and skills through training programmes on transcultural issues.

- Involve various cultural groups in decision-making in health promotion to improve primary health care practice.

\subsection{Health related legislation}

The health related legislation should:

- Direct the community nurse to prescribe and administer treatment to individuals with health problems (Medicine and Related Substance Control Act 90 of 1997).

- $\quad$ Provide information about regulations on the Scope of Practice that facilitate community nurses functioning within the primary health care setting (Regulation for Scope of Practice, R2676 of 1990).

- Guide decision-making on professional and ethical issues by translating the legislation into action in the language understood by the students in the primary health care setting, for example decisions about the termination of pregnancy (Termination of Pregnancy Act 92 of 1996).

- $\quad$ Provide guidelines on effective labour relation issues, such as accepted recognition and negotiation agreement with health worker organisations on matters such as service conditions and clear grievance procedures, which will help to avoid strikes or other industrial actions which would compromise health care of members of the community (Labour Relation Amendment Act 42 of 1996).

- $\quad$ Provide guidance on the execution of primary health care within the scope of practice of the community nurse, to enhance independent functioning. Each student nurse should be in possession of a copy of the Regulations for Scope of Practice and copies of health related legislation to guide their actions in practice.

\subsection{Intersectoral and multi-disciplinary collaboration}

In order to ensure an intersectoral and multi-disciplinary approach in the primary health care setting, nurse educators/community nurses should:

- $\quad$ Equip student nurses with the necessary skills in consultation and networking with health related sectors and other professional disciplines.

- Prepare student nurses to make proper referral of persons with health needs/ problems for primary health care intervention.

- Establish effective communication channels with social workers, physiotherapists, dieticians and other community organisations that are health related. 


\begin{tabular}{|c|c|}
\hline CATEGORIES & GUIDELINES \\
\hline & $\begin{array}{l}\text { Provide knowledge and skills in respect of the role of the following intersectoral } \\
\text { service in the provision of primary health care in the community: } \\
\text { nutritional services which provide adequate and proper food supplies to prevent } \\
\text { nutrition related health problems; } \\
\text { water supply services which provide adequate safe water for consumption, hy- } \\
\text { giene and industrial purposes; } \\
\text { sanitation services for adequate and safe waste disposal in preventing health } \\
\text { problems. } \\
\text { Hold Community Nursing Science Committee meeting with community nurs- } \\
\text { ing experts, experts in health-related sectors and student nurses. } \\
\text { Members of the Community Nursing Science Curriculum Committee must be } \\
\text { encouraged to provide input and feedback on primary health care areas that should be } \\
\text { improved and on identified community needs/problems. }\end{array}$ \\
\hline $\begin{array}{l}\text { 4. Selection and organisation } \\
\text { of methods/learning opportunities } \\
\text { of an integrated Community } \\
\text { Nursing Science Curriculum. }\end{array}$ & $\begin{array}{l}\text { These methods should include the following: } \\
\text { - Family studies, seminars, workshops, fieldwork, interactive group discussions, } \\
\text { portfolios, problem-solving, workbooks, community awareness campaigns, film and } \\
\text { video shows, brainstorming and community development projects and dialogue. } \\
\text { - Group discussions and seminars should be held with student nurses, health re- } \\
\text { lated sectors, professionals, community representatives, women's organisations, com- } \\
\text { munity leaders, church leaders and youth groups in the community health centres, } \\
\text { clinics, schools, workplaces and non-governmental health care centres. } \\
\text { - Involvement of community members in identification of their own health needs } \\
\text { and development of the capacity to plan how to meet those needs. } \\
\text { - Experts in health related sectors must be involved to guide student nurses in } \\
\text { their fields of specialisation, for example, affordable technology in dealing with com- } \\
\text { mon health problems, such as protection against malaria mosquitoes, life-skills to ap- } \\
\text { ply in common health emergencies in the community. } \\
\text { - Involvement of learning facilitators in accompaniment programmes for student } \\
\text { nurses in the primary health care setting. The necessary orientation and guidance } \\
\text { programmes on integrated Community Nursing Science Curriculum should be pro- } \\
\text { vided. } \\
\text { - Student nurses should be placed in the primary health care setting from the first } \\
\text { year to the last year of their training, following theoretical learning experiences, in } \\
\text { order to correlate and apply theory to practice. } \\
\text { - Student nurses must also be allocated to clinics, families, schools, creches, nurs- } \\
\text { eries, workplaces and prisons. }\end{array}$ \\
\hline $\begin{array}{l}\text { 5. Evaluation in an inte- } \\
\text { grated Community Nursing Sci- } \\
\text { ence Curriculum }\end{array}$ & $\begin{array}{l}\text { Evaluation of the curriculum should be both student and curriculum orientated and } \\
\text { should include both the theoretical and clinical learning experiences. } \\
\text { - Student orientated evaluation should include the following: } \\
\text { continuous evaluation, self-evaluation, peer group evaluation, use of portfolios, } \\
\text { formative and summative evaluation; } \\
\text { - student nurses should be given the opportunity to evaluate their own perform- } \\
\text { ance at different levels of training and education to recognise their limitations to im- } \\
\text { prove their learning skills; } \\
\text { both nurse educators and community nurses who participated in the education } \\
\text { and training of student nurses should take part in the clinical examination of an inte- } \\
\text { grated Community Nursing Science Curriculum; } \\
\text { - evaluation should be formative and summative in nature, i.e. continuous clini- } \\
\text { cal evaluation and clinical examination. Evaluation should be conducted immediately } \\
\text { after student's exposure to the practica area. } \\
\text { - Curriculum-orientated evaluation should include continuous evaluation in or- } \\
\text { der to determine the extent to which the primary health care approach has been inte- } \\
\text { grated into the Community Nursing Science Curriculum. Each phase of the integrated } \\
\text { Community Nursing Science Curriculum must be evaluated continuously. Research } \\
\text { should be conducted four years after implementation of the integrated curriculum to } \\
\text { determine if primary health care approach had, in fact, been integrated into the Com- }\end{array}$ \\
\hline
\end{tabular}




\begin{tabular}{|l|l|}
\hline CATEGORIES & GUIDELINES \\
\hline \multirow{1}{*}{$\begin{array}{l}\text { munity Nursing Science Curriculum. } \\
\text { applied both in theoretical and practical evaluation. Comprehensive interactive evalu- } \\
\text { ation methods, such as portfolios, projects, workbooks, assignments, peer-group as- } \\
\text { sessment and self-assessment should be used. } \\
-\quad \text { Student nurses knowledge, skills, attitudes and academic development in pri- } \\
\text { mary health care should be determined. Ensure continuous assessment of student nurses } \\
\text { both in theoretical and practical component of the integrated curriculum. } \\
-\quad \text { Formative and summative evaluation must be conducted at every level of stu- } \\
\text { dent nurses' education and training to determine progress in students exposure to the } \\
\text { practical area. } \\
\text { Nurse educators and community nurses who participated in the community- } \\
\text { based education of student nurses must be involved in clinical evaluation. }\end{array}$} \\
\hline
\end{tabular}

\section{References}

AFRICAN NATIONAL CONGRESS (ANC) 1994: A National Health Plan for South Africa. Johannesburg: Bähr.

\section{AMERICAN ASSOCIATION OF COLLEGES OF NURS- \\ ING 1993: Addressing nursing education's agenda for the 2 lst century (Position statement). Washington, DC Author.}

ANDREWS, M 1995: Transcultural Nursing: Transforming the Curriculum. Journal of Transcultural Nursing, 6(2): 4-10.

BEDDONE, G; BUDGEN, C; HILLS, MD; LINDSEY, AE; DUVAL, PM \& SZALAY, L 1995: Education and practice collaboration: A strategy for curriculum development. Journal of Nursing Education, 34(1): 11-15.

BESTARD, S \& COURTENAY, M 1990: focussing on wellness. The Canadian Nurse, 86(11): 24-25.

BERMAN, J \& MULLER, M 1994: The views of primary health care practitioners regarding legal limitations influencing the practice of primary health care in South Africa. Curationis, 17:29-32.

CARL, AE 1995: Teacher empowerment through curriculum development: Theory into practice. Cape Town: Juta.

CRESWELL, JW 1994: Research design: qualitative and quantitative approaches. New Delhi: SAGE.

DE TORNYAY, R 1993: Nursing Education: Staying on tract. Nursing and Health Care, 14:302-306.

DEPARTMENT OF NATIONAL HEALTH 1997: White Paper for the Transformation of the Health System in South Africa. Vol. 382, No. 17910. Pretoria: Government Printer.

DRYER, M; HATTING, S \& LOCK, M 1993: Fundamental aspects in community health nursing. Halfway House: Southern Books.

EDELSTEIN, G \& SANDERS, D 1998: An assessment of the exit competencies of professional nurses in relation to those required to implement the National Health System at district level: the implication for nursing education. University of the Western Cape: Centre for Health, Human Resources.

ESHLEMAN, J \& DAVIDHIZAR, R 1997: Community Nursing Education: A five star process International Nursing Review, 44(1): 24-28.

FAIRLEY, S 1993: The Community as partner in primary health care. Nursing and health Care, 14:244-249.

FUSZARD, B 1995: Innovating teaching strategies in Nursing. Second Edition. Maryland, USA: An Aspen Publication.

HILLS, MD \& LINDSEY, AE 1994: University College Collaboration: Re-thinking curriculum development in Nursing Education. Journal of Nursing Education, 33(5):220225.

KNOWLES, MS 1980: The modern practice of adult education. From Pedagogy and Andragogy. New York: The Adult Education Co.

KREFTING, L 1991: Rigor in qualitative research: the assessment for trustworthiness. The American Journal of OCcupational Therapy. 45(3): 214-222.

LINCOLN, YS \& GUBA, EG 1985: Naturalistic inquiry. London: SAGE.

LONG, HB 1993: Adult Learning. Research and practice New York: Cambridge.

MELLISH, JM \& BRINK, HIL 1998: Teaching and learning the practice of Nursing. Johannesburg: Heinemann.

MOUTON, J \& MARAIS, H 1990: Concepts in the methodology of Social Sciences. Pretoria: Human Sciences Re- 
search Council.

NICHOLLS, A \& NICHOLLS, SH 1972: Developing a Curriculum. A practical guide. London: George Allen \& Unwin.

OERMANN, M 1994: Reforming nursing education for future practice. Journal of Nursing Education, 33(5): 215-219.

ORAL ROBERTS UNIVERSITY ANNA VAUGHN SCHOOL OF NURSING 1992: Self study report submitted on the Council of Baccalaureate and Higher Degree Programs, National League for Nursing. August, 1990. Volume 1 Narrative by criteria. Tulsa, Oklahoma: ORU Anna Vaughn School of Nursing.

RAND AFRIKAANS UNIVERSITY 1994: Nursing for the Whole Person Theory. Auckland Park: RAU (Department of Nursing).

REED, J \& PROCTER, S 1993: Nurse education: a reflective approach. London: Edward Arnold.

REPUBLIC OF SOUTH AFRICA 1996: The Constitution of the Republic of South Africa. Act 108 of 1996. Pretoria: Goverment Printers.

SOUTH AFRICA (REPUBLIC) 1996: Termination of Pregnancy Act (Act 92 of 1996). Pretoria: Government Printers.

SOUTH AFRICA (REPUBLIC) 1996: Labour Relations Amendment Act (Act 42 of 1996). Pretoria: Government Printers.

SOUTH AFRICA (REPUBLIC) 1995: Nursing Amendment Act (Act 5 of 1995) Pretoria: Government Printer.

SOUTH AFRICA (REPUBLIC) 1997: The Medicine and Related Substance Control Amendment Act (Act 90 of 1997). Pretoria: Government Printers.

SOUTH AFRICAN NURSING COUNCIL 1990: Regulation for the Scope of Practice, R2676 of November 1990. Pretoria: SANC.

SPRADLEY, BW 1990: Community Health Nursing concepts and practice. London: Scott \& Foreman.

TESCH, R 1990: Qualitative research analysis types and soft ware. New York: Falme.

TROSKIE, $R$ 1997: The role of the health care worker in collaboration with traditional healers in Primary Health Care. Part 1 and Part 2. Health SA Gesondheid, 2(1):28-40.

WOODS, NF \& CATANZARO, M 1998: Nursing Research, Theory and Practice. St. Louis: CV Mosby.

WORLD HEALTH ORGANISATION 1978: Primary Health Care. Report on the International Conference on Primary Health Care. Alma Ata. USSR, 6 - 12 September 1978. Geneva: WHO. 